УДК 657.631:336

Разборська О.О., к.е.н, доцент, доцент кафедри обліку, аналізу і аудиту Донецького національного університету імені Василя Стуса

Левченко І.А., здобувач Вінницького фрінансово-економічного університету

\title{
ОСОБЛИВОСТІ ЗАСТОСУВАННЯ ФІНАНСОВОЇ ЗВІТНОСТІ БАНКІВСЬКИМИ УСТАНОВАМИ УКРАЇНИ ЗА МСФЗ
}

У статті досліджено особливості складання фінансової звітності банківськими установами відповідно до вимог Міжнародних стандартів фінансової звітності та Національного банку України. Обгрунтовано, що головним кінцевим показником, який характеризує діяльність банківської установи, їі фінансовий і майновий стан, надає інформацію внутрішнім і зовнішнім користувачам для прийняття обгрунтованих i зважених економічних рішень, є фінансова звітність. Застосування банками у своїй діяльності міжнародних стандартів дає можливість відображати у звітності якісну і повну фінансову інформацію. Зазначено, що ефективне управління банком значною мірою залежить від повноти, обгрунтованості та достовірності звітної інформації: про здійснені операції, їхній характер і обсяг; наявність фінансових ресурсів i напрямів їх використання; ризики банківської діяльності.

Визначено необхідність застосування МСФЗ банками України та сформульовано переваги складання фінансових звітів за Міжнародними стандартами в умовах сучасного розвитку вітчизняного банківського сектору.

Ключові слова: фінансова звітність, Міжнародні стандарти фінансової звітності, банківські установи, банки.

Рис. 1, Літ. 7.

\section{Разборська Е.А., Левченко И.А.}

\section{ОСОБЕННОСТИ ПРИМЕНЕНИЯ ФИНАНСОВОЙ ОТЧЕТНОСТИ БАНКОВСКИМИ УЧРЕЖДЕНИЯМИ УКРАИНЫ ПО МСФО}

В статье исследованы особенности составления финансовой отчетности банковскими учреждениями в соответствии с требованиями Международных стандартов финансовой отчетности и Национального банка Украины. Обосновано, что главным конечным показателем, характеризующим деятельность банковского учреждения, ее финансовое и имущественное состояние, предоставляет информацию внутренним и внешним пользователям для принятия обоснованных и взвешенных экономических решений, является финансовая отчетность. Применение банками в своей деятельности международных стандартов дает возможность отражать в отчетности качественную и полную финансовую информацию. Определено, что эффективное управление банком в значительной степени зависит от полноты, обоснованности и достоверности отчетной информации: об осуществленных операциях, их характер и объем; наличие финансовых ресурсов и направлений их использования; риски банковской деятельности.

Доказана необходимость применения МСФО банками Украины и сформулированы преимущества составления финансовых отчетов с помощью Международных стандартов в условиях современного развития отечественного банковского сектора.

Ключевые слова: финансовая отчетность, Международные стандарты финансовой отчетности, банковские учреждения, банки. 
Razborska E., Levchenko I.

\section{THE FEATURES APPLICATION OF FINANCIAL STATEMENTS BY BANKING INSTITUTIONS OF UKRAINE IN ACCORDANCE WITH IFRS}

The features of financial statements by banking institutions in accordance with International Financial Reporting Standards and the National Bank of Ukraine are researched in the article. It is substantiated that the main endpoint characterizing the activities of a banking institution, its financial and property status, provides information to internal and external users for the adoption of reasonable and well-considered economic decisions is financial statements. The use of banks in their activities of international standards enables them to report qualitative and complete financial information. It is determined that effective management of the bank depends to a great extent on the completeness, validity and reliability of the reporting information: on the transactions carried out, their nature and scope; availability of financial resources and directions of their use; banking risks.

The necessity of application IFRS by banks of Ukraine is proved and benefits of preparation of financial statements according to international standards in the modern development of the domestic banking sector are formulated.

Keywords: financial reporting, International Financial Reporting Standards, bank institutions, banks.

Постановка проблеми. Сьогоденний вектор розвитку України направлений на створення власної економіки ринкового спрямування. Одним із визначальних економічних важелів управління $є$ саме банківська система, яка відіграє надважливу роль як на внутрішньому ринку України, так і у світовій господарській системі.

Нові умови господарювання спонукають банківські установи до оперативного та вчасного реагування на інформацію, що надходить із зовнішніх і внутрішніх джерел аналітичних підрозділів. Натомість, потреба в розширенні обсягу та змісту якісної інформації значно зростає, що спричинює, як наслідок, підвищені вимоги до бухгалтерського обліку та аудиту в банківських установах. Значний відсоток банків України мають фінансово-господарські відносини із зовнішніми партнерами, тому складання фінансової звітності банківськими установами відповідно до Міжнародних стандартів фінансової звітності $\epsilon$ питанням, яке потребує особливого розгляду та залишається актуальним на сьогоднішній день.

Аналіз останніх досліджень і публікацій. Поняття бухгалтерського обліку та значення фінансової звітності на підприємствах, установах та організаціях досліджували Ф.Ф. Бутинець, В.В. Сопко, М.Й. Малік, С.Ф. Костюченко та ін. Серед сучасних економістів, що розглядають питання доцільності використання МСФЗ під час складання фінансової звітності у банках можна виділити А.М. Герасимовича, С.Ф. Голова, В.І. Ричаківську, Л.М. Кіндрацьку, Ж.К. Несторенко та ін. Здійснивши аналіз цих праць, можна свідчити, що є різні точки зору з приводу досліджуваної теми, починаючи від рекомендації та пропозицій щодо впровадження Міжнародних стандартів фінансової звітності у національну систему обліку і формування фінансової звітності за МСФЗ та до повного неприйняття цього процесу як такого.

Виділення невирішених раніше частин загальної проблеми. Слід зазначити, що на даному етапі економічного розвитку залишається певне коло не вирішених питань стосовно повноти впровадження МСФЗ в обліку українських банківських структур, причинами яких є існування необхідності адаптації звітності за МСФЗ 3 дотриманням вимог українського законодавства до загальноприйнятого світового 
формату фінансової звітності та її обліку.

Мета статті полягає у дослідженні необхідності складання фінансової звітності відповідно до МСФЗ українськими банками та визначення ролі обліку в системі управління банківської установи.

Виклад основного матеріалу дослідження. Системою реєстрування та підбиття підсумків операцій, виконуваних у банківському бізнесі, з подальшим аналізом та перевіркою результатів і складанням відповідних звітів є бухгалтерський облік банку, який характеризується оперативністю і єдністю форми побудови. Це проявляється в тому, що всі розрахункові, кредитні та інші операції, вчинені в банку протягом операційного часу, в той же день відображаються на особових рахунках аналітичного бухгалтерського обліку і контролюються шляхом складання щоденного бухгалтерського балансу установи банку. Єдина для всіх банків система обліку є необхідною умовою аналізу банківської діяльності [1, с. 148].

Зауважимо, що бухгалтерський облік $є$ важливим елементом структури внутрішнього контролю. Так, на управлінські рішення істотно впливає бухгалтерська інформація щодо готівки, розрахунків, цінних паперів банку, депозитних операцій, кредитних ресурсів та кредитного портфеля. Ефективне управління банком значною мірою залежить від повноти, обгрунтованості та достовірності звітної інформації: про здійснені операції, їхній характер і обсяг; наявність фінансових ресурсів і напрямів їх використання; ризики банківської діяльності [2, с. 28].

Бухгалтерська інформація базується на документах, які дають змогу простежити рух активів від моменту отримання таких до списання чи реалізації. Те саме стосується й пасивів - від виникнення зобов'язань до їх погашення. Адже банк не може успішно функціонувати в конкурентному середовищі без відповідної системи щоденного обліку всіх своїх операцій і зобов'язань. Лише за такої умови керівництво цієї установи постійно простежує всі аспекти ії діяльності, а отже, і ризики, на які вона наражається. Ця інформація має бути надана у відповідний час, бути якісною та повною. Тільки достовірна інформація може реально відображати фінансовий стан банку [2, с. 36].

Як наслідок, банківська звітність, як важливий інструмент управління, який відображає результати діяльності банку, його майновий і фінансовий стан, дотримання банком фінансової дисципліни при виконанні передбачених статутом операцій, забезпеченість відповідними джерелами коштів для своєчасного виконання зобов'язань i розвитку банку $\epsilon$ основною складовою інформаційного забезпечення прийняття економічних рішень суб'єктами фінансового ринку.

Реформування бухгалтерського обліку та фінансової звітності в банківській системі відбувалося шляхом розроблення Національним банком України (НБУ) нормативно-правових актів, що регламентують порядок відображення в бухгалтерського обліку типових операцій та встановлення вимог до складання фінансової звітності у відповідності до МСФЗ.

На сьогодні фактично побудовано систему бухгалтерського обліку та фінансової звітності, яка грунтується на вимогах міжнародних стандартів. Фінансова звітність, що складена за вимогами Національного банку, практично в усіх аспектах відповідає МСФЗ, крім порядку формування та використання резервів під знецінення фінансових активів.

У процесі реформування системи бухгалтерського обліку України основне завдання полягає у зближенні Національних стандартів бухгалтерського обліку до Міжнародних стандартів фінансової звітності. Процес складання фінансової звітності за МСФЗ є складним і трудомістким, оскільки має відповідну методику. Однак необхідність впровадження МСФЗ у вітчизняну практику підтверджується основними перевагами 
Міжнародних стандартів, а саме:

- формування якісної, прозорої та надійної звітності за єдиними правилами;

- можливість прийняття ефективних управлінських рішень за допомогою використання інформації наведеної у звітах;

- можливість перевірки фінансової звітності світовими аудиторськими компаніями;

- створення умов для залучення іноземних інвестицій та позикового капіталу, вихід на зарубіжні ринки [3].

До теперішнього часу в міжнародній практиці склалися три варіанти впровадження Міжнародних стандартів фінансової звітності:

1) застосування МСФ3 паралельно 3 національними правилами обліку та звітності;

2) визнання МСФЗ в якості національних стандартів бухгалтерського обліку та фінансової звітності;

3) розробка національних стандартів фінансової звітності на основі МСФЗ, тобто 3 незначними відмінностями, враховують особливості національної облікової системи.

При паралельному використанні МСФЗ та національних стандартів (перший варіант) пріоритет віддається національній системі бухгалтерського обліку, а звітність за міжнародними стандартам формується або шляхом трансформації даних 3 фінансової звітності, підготовленої відповідно до вимог національного законодавства, або за допомогою ведення паралельного обліку. У другому і третьому випадках, як додаток до формування фінансової звітності, міжнародні стандарти також можуть бути взяті за основу визначення порядку ведення бухгалтерського і податкового обліку.

За час пристосування національної системи обліку та звітності відповідно до вимог МСФЗ пройдено шлях від поверхневого і теоретичного розуміння і застосування МСФЗ до їх досить професійного і практичного застосування. Фінансова звітність банку є результатом обробки великої кількості операцій, які класифікують за певними ознаками та об'єднують у групи. Кінцевим етапом у цьому процесі є подання стислих і класифікованих даних, які формують статті у фінансовій звітності. Фінансова звітність $є$ структурованим відображенням фінансового стану та фінансових результатів діяльності банку, а також основним засобом донесення фінансової інформації про нього зовнішнім користувачам щодо результатів діяльності банків; створює достовірну базу для визнання доходів і витрат, оцінки активів і зобов'язань; надає можливість об'єктивно розкривати і віддзеркалювати наявні фінансові ризики; порівнювати результати діяльності банків для забезпечення адекватної оцінки їхнього потенціалу та ухвалення відповідних управлінських рішень.

Метою фінансової звітності банку є надання інформації про фінансовий стан, результати діяльності та грошові потоки банку, яка $є$ корисною для широкого кола користувачів при прийнятті ними економічних рішень. Корисність інформації, яка подається у фінансовій звітності, залежить від того в якій мірі вона відповідає якісним характеристикам. Згідно з Концептуальною основою фінансової звітності (опублікованою РМСБО у 2010 р.), для того, щоб інформація, яка розміщена у фінансовій звітності (тобто фінансова інформація) була корисною, вона повинна бути доречною та правдиво подавати те, що вона призначена подавати. Корисність фінансової інформації посилюється, якщо вона $\epsilon$ зіставною, її можна перевірити, вчасною та зрозумілою [4].

Розглянемо більш детально якісні характеристики, які наводяться у Концептуальній основі фінансової звітності. Доречність та правдиве подання $\epsilon$ основоположними якісними характеристиками. Доречна фінансова інформація може спричинити відмінності у рішеннях, які приймають користувачі. Фінансова інформація 
може спричинити відмінності у рішеннях, якщо вона має передбачувальну цінність, підтверджувальну цінність або обидві. Передбачувальна цінність та підтверджувальна цінність фінансової інформації взаємопов' язані між собою [5, с. 47].

Реформування бухгалтерського обліку та фінансової звітності в Україні зумовило ряд економічних та технологічних змін. За останні два десятиліття створено інформаційну інфраструктуру для ефективного управління банком, фінансова звітність банківських установ стала більш зрозумілою та доступною для зовнішніх користувачів, впроваджено нові фінансові інструменти в діяльність комерційних банків, створено інструментарій банківського нагляду, розвивається внутрішній банківський контроль та система управління ризиками, впроваджуються нові інформаційні технології, програмні продукти, облікові та аналітичні підсистеми [6, с. 21].

Зацікавленість зовнішніх користувачів фінансової звітності банківської установи полягає в отриманні повної, достовірної та такої, яка може надати певне уявлення про рівень надійності банку. Велике значення у розвитку діяльності банку, а саме у залученні іноземних клієнтів та партнерів або інвесторів має однозначність тлумачення змісту фінансової звітності користувачами різних країн. Саме тут постає питання використання МСФЗ для порівнянності та прозорості звітності українських банківських установ з даними звітності закордонних компаній банківського сектору. На нашу думку, використання МСФЗ забезпечить користувачів фінансової звітності банківської установи достовірною та повною інформацією щодо фінансового стану та результатів іiі діяльності, яка може надати певне уявлення про рівень надійності банку.

На думку С.А. Легкої [7], серед основних проблем під час переходу до застосування МСФЗ можна виділити:

- недосконалість організації процесу впровадження МСФЗ;

- необхідність складання облікової політики за МСФЗ, що суттєво вплине на весь процес відображення в обліку господарських операцій підприємств різних організаційно-правових форм, у тому числі й банківських установ;

- визначення периметра консолідації звітності;

- забезпечення автоматизації складання фінансової звітності за наявності відповідного програмного забезпечення.

На нашу думку, основна проблема на шляху переходу банківських установ до застосування МСФЗ під час складання фінансової звітності полягає в недостатній мобільності та гнучкості до змін. Так вітчизняне законодавство стрімко змінюється, часто не відповідаючи вимогам міжнародних норм. Фінансова звітність банків у цілому відповідає вимогам МСФЗ, але облік банківські установи ведуть за нормами України. Проте між показниками вітчизняної та міжнародної звітності є вагомі розбіжності, які необхідно усувати, але для цього немає визначеної єдиної методики. Неузгодженість та часті зміни окремих законодавчих норм, що вимагають постійного моніторингу вимог законодавства, неоднозначного їх тлумачення контролюючими органами та банками, призводить до виникнення помилок. Це, у свою чергу, має такі негативні наслідки, як зростання юридичного ризику, штрафи, необхідність грошового відшкодування збитків, погіршення репутації, погіршення позиції банку на ринку, звуження можливостей для розвитку бізнесу, зменшення можливостей правового забезпечення виконання договорів.

Відзначимо, що повному впровадженню звітування за вимогами МСФЗ заважають великі податкові ризики, які виникнуть у банків при проведенні перевірок податківцями щодо правильності ведення банком бухгалтерського обліку відповідно до міжнародних стандартів та правильності і повноти визначення доходів, витрат та фінансового результату до оподаткування згідно з бухгалтерським обліком відповідно до МСФЗ. 
Також, практика показала, що банки України виявилися неготовими до формування фінансової звітності за МСФЗ, що пов'язано з недостатньою кваліфікацією бухгалтерського персоналу та недосконалістю законодавчо-нормативного забезпечення щодо обсягу та змісту фінансової інформації у звітах.

У процесі дослідження нами проаналізовані проблеми, що виникають у процесі впровадження міжнародних стандартів, а також, як наслідок, можливі шляхи розв'язання цих проблем. Схема процесу адаптації фінансової звітності банків України до вимог до МСФЗ зображена на рис. 1.

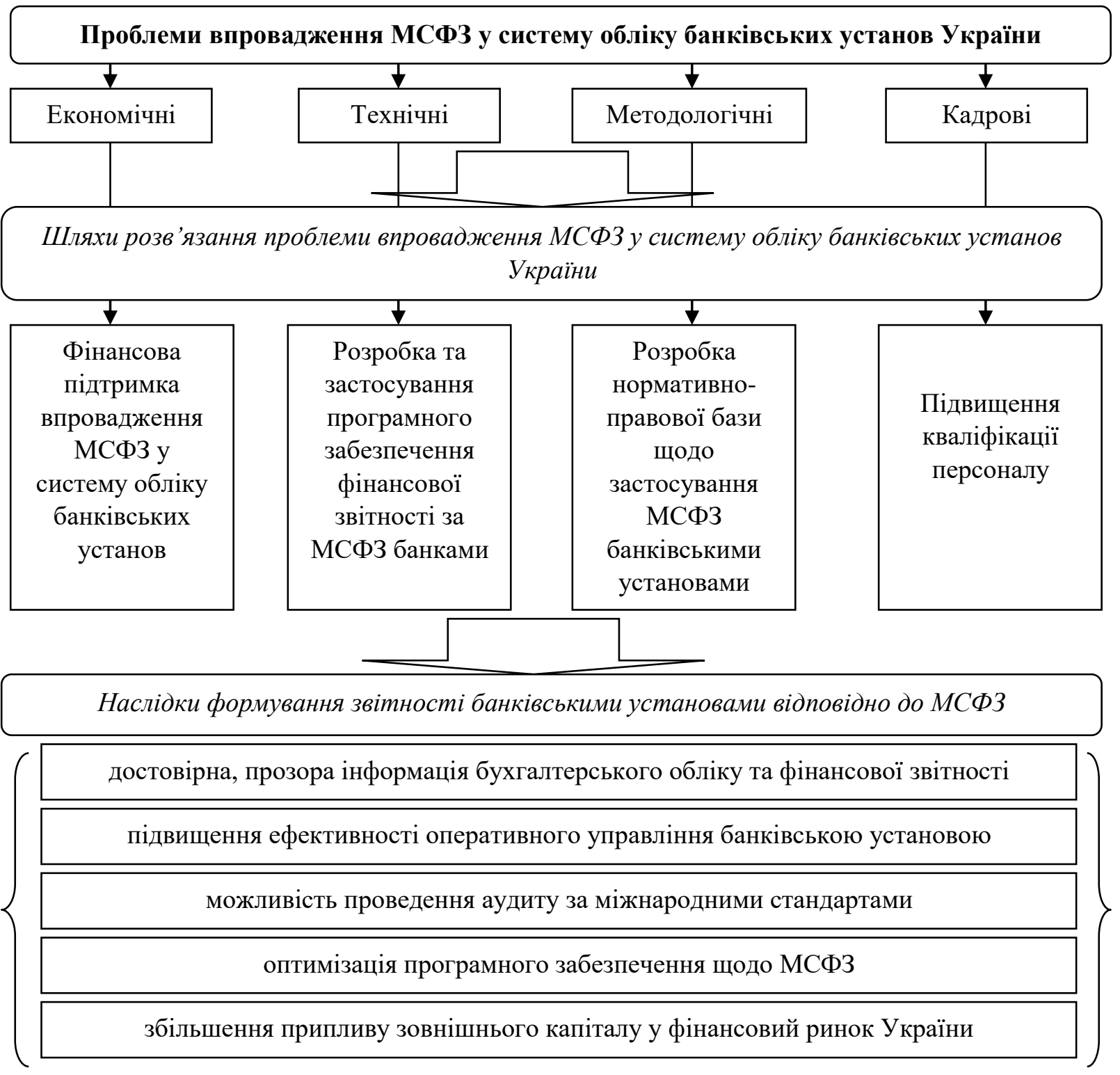

Рисунок 1 - Схема процесу адаптації фінансової звітності банків

України до вимог за МСФЗ

На нашу думку, перевагою використання МСФЗ під час складання фінансової звітності можна виділити реальну можливість отримання інформації для прийняття управлінських рішень, які, з огляду на існуючу ситуацію в країні, особливо необхідні. Ретельний i рішучій підхід до впровадження МСФЗ у банківських установах забезпечить установлення нового рівня довіри з боку потенційних партнерів, а також залучення іноземних інвестицій і позик, що сприятиме виходу вітчизняних банківських 
структур на міжнародні ринки.

Тому для забезпечення швидкого реагування керівництва банківських установ в Україні щодо змін та особливостей складання фінансової звітності за вимогами МСФЗ необхідно:

- вдосконалювати нормативно-правову базу щодо регулювання бухгалтерського обліку банків в Україні, наближену до світового досвіду;

- сприяти розвитку фінансових ринків шляхом надання прозорої, чіткої та правдивої інформації користувачам фінансової звітності банків;

- удосконалювати програмні продукти стосовно автоматизації бухгалтерського обліку в банках відповідно до Міжнародних стандартів;

- удосконалювати існуючі та розроблювати нові форми управлінської звітності банківських установ 3 метою оптимізації даних для прийняття ефективних управлінських рішень;

- удосконалювати та раціонально розподіляти фінансування державного регулювання впровадження МСФЗ в Україні.

Висновки. Законодавчі зміни, що відбулися останнім часом в плані реформування бухгалтерського обліку, $є$ реальним поштовхом до запровадження застосування МСФЗ в Україні. Міжнародні стандарти фінансової звітності виступають ефективним інструментом отримання повної і зрозумілої для всіх користувачів інформації про діяльність банківських установ, порівняння результатів їх діяльності 3 метою забезпечення адекватної оцінки їх потенціалу та ухвалення відповідних управлінських рішень у світлі приєднання України до світової економіки.

На нашу думку, перехід на міжнародні стандарти фінансової звітності $є$ принципово необхідним. Це збільшить довіру клієнтів до банків, оскільки, МСФЗ роблять прозорою діяльність банків, дають можливість користувачам отримувати достовірну інформацію щодо банківської діяльності.

\section{Література:}

1. Єлисєєва О.К. Особливості складання фінансової звітності банківськими установами України / О.К. Слисєєва, А.О. Нетета // Науковий вісник Херсонського державного університету. - 2015. - Вип. 11. - Ч. 3. - С. 147-150.

2. Фінансовий облік та фінансова звітність у банках: Навчальний посібник / Національний банк України; За заг. Ред.. Г.П. Табачук, О.М. Сарахман. - К.: УБС НБУ, 2007. - 430c.

3. Колісник В.Ю. Проблеми і перспективи складання фінансової звітності відповідно до Міжнародних стандартів обліку та звітності / В.Ю. Колісник [Електронний ресурс]. - Режим доступу : http://repository.hneu.edu.ua/.

4. Концептуальна основа фінансової звітності [Електронний ресурс]. - Режим доступу: http:// www . zakon4.rada.gov.ua/laws/show/929_009

5. Литвин Н. Б. Фінансовий облік у банках (у контексті МСФЗ) [Текст] : підручник / Н. Б. Литвин. - [2-ге вид., доп. і перероб.]. - К. : «Центр учбової літератури», 2017. - 676 с.

6. Касич А.О. Проблеми впровадження МСФЗ в України та шляхи їх вирішення / А.О. Касич, Я.Ю. Яковенко // Облік і фінанси. - 2013. - № 1(59). - С. 22 27.

7. Легка С.А. Актуальні проблеми переходу українських підприємств на Міжнародні стандарти фінансової звітності / С.А. Легка // Студентський вісник Національного університету водного господарства та природокористування [Електронний ресурс]. - Режим доступу : http://ep3.nuwm.edu.ua/. 